\title{
Effects of different neutraceutic supplements on the gastric mucosa of weanling foals
}

\author{
Alexandra Fedtke ${ }^{7}$, Arne Fiedler ${ }^{2}$, Monica Venner ${ }^{1}$ und Ingrid Vervuert ${ }^{2}$ \\ 1 Equine Veterinary Clinic, Destedt, Germany \\ 2 Institute of Animal Nutrition, Nutrition Diseases and Dietetics, Faculty of Veterinary Medicine, University of Leipzig, Germany
}

\begin{abstract}
Summary: Weaning can be a stressful period in foal's life resulting in increased prevalence of gastric ulcers which may lead to impaired rearing performance and economical losses. Beside medical treatment and optimizing housing and feeding conditions, dietary supplements have been proposed to reduce gastric mucosal lesions. Sixty-one warmblood weanlings from one stud farm, aged between 6 and 8 months were included in the study. During the experimental period, all foals were fed a total mixed ration (TMR) and hay ad libitum. After weaning, all foals were randomly and blindly allocated to one of three supplementation groups: group 1, control foals with no supplements; group 2, supplemented with $\mathrm{MgO}$; and group 3, supplemented with a fermented preparation of herbs. Gastroscopy was performed prior to weaning and again after 16 days of feeding. Before weaning, the prevalence of gastric mucosal lesions was $82 \%$ mainly found in the Curvatura minor of the Pars nonglandularis. After weaning, the prevalence was $96.7 \%$. The Antrum pyloricum and the Curvatura minor of the Pars nonglandularis showed a significant increase in gastric mucosa lesions after weaning in all groups. In both treatment groups, weaning resulted in a significantly higher lesion score in the Pars nonglandularis of the Curvatura major and on the pylorus and did not reduce the gastric lesion scores.
\end{abstract}

Keyword: EGUS / magnesium oxide / weanling / fermented herbs / nutrition

Citation: Fedtke A., Fiedler A., Venner M., Vervuert I. (2015) Effects of different neutraceutic supplements on the gastric mucosa of weanling foals. Pferdeheilkunde 31, 364-370

Correspondence: PD Dr. Ingrid Vervuert, Universität Leipzig, Institut für Tierernährung, Ernährungsschäden und Diätetik, An den Tierkliniken 9, 041043 Leipzig, Germany, E-Mail: ingrid.vervuert@vetmed.uni-leipzig.de

\section{Introduction}

Equine gastric ulcer syndrome (EGUS) is a very common health problem in adult horses and foals. The prevalence of EGUS in thoroughbred racehorses is estimated to be $>80 \%$ (Vatistas et al. 1994). The prevalence of EGUS in foals ranges between 30 and $50 \%$ (Andrews et al. 1999) particularly in weanlings (Dahlkamp et al. 2012). In addition to the specific characteristics of the continuous production of hydrochloric acid by the parietal cells of the glandular mucosa in horses, several mechanisms are discussed to induce gastric ulceration (Andrews et al. 1999, Murray 1999). Other acids, including bile acids or short chain fatty acids (SCFA), have also been implicated in acid injury. SCFA, such as butyrate, acetate and propionic acid, act synergistically with hydrogenic acid and induce similar effects by penetrating the mucosa, thereby resulting in cellular swelling and inflammation as well as interacting with the sodium transport system (Nadeau et al. 2003). Furthermore, carbohydrate fermentation by microflora produces lactic acid and induces increased tissue permeability and secondary damages of the equine stomach mucosa (Al Jassim et al. 2008). In contrast to the severe impact in human patients, Helicobacter pylori is only sporadically identified in the stomach of horses with EGUS, therefore the role of this pathogen remains unclear (Contreras et al. 2007). Risk factors, such as nonsteroidal anti-inflammatory drugs, high grain diets, starvation periods for $24 \mathrm{~h}$, stall confinement, strenuous exercise or transport stress have been identified to induce equine gastric ulcer syndrome (Murray 1994, Andrews et al. 1999, Murray and Eichorn 1996, Murray and Grady 2002). In foals, the weaning process is well known to induce gastric ulceration (Hammond et al. 1990, Dahlkamp et al. 2012).
Several studies have confirmed an improvement of healing gastric ulcers by administering drugs, such as omeprazole (Birkmann et al. 2014), cimetidine and ranitidine (Lester et al. 2005). In addition to medical treatment, optimizing feeding and housing management is highly recommended. For example, forage should be provided ad libitum or at least to a daily minimum of $1.5 \%$ of BW based on dry matter intake (Coenen et al. 2011 ). In exercising horses, grain intake should be limited to a maximum of $1 \mathrm{~g} \mathrm{starch/} / \mathrm{kg}$ BW per meal (Vervuert et al. 2009). Several dietary supplements preventing and supporting the gastric mucus layer are commercially available. An improved recovery of EGUS by feeding a commercial pectinlecithin supplement has been reported by Venner et al. (1999) and Ferruci et al. (2003), whereas Murray and Grady (2002) and recently Sanz et al. (2014) could not find any preventive effect in a gastric ulceration model using an intermittent fasting protocol. Administration of magnesium oxide $(\mathrm{MgO})$ resulted in a transient increase in the gastric $\mathrm{pH}$ of up to 6 (Murray and Grodinsky 1992). The buckthorn berry has also been highlighted as a feed supplement that is used to prevent gastric ulceration in horses. In particular, glandular ulcer scores were lower in horses, which were fed a commercial product with buckthorn berries using an intermittent feeding protocol to induce gastric ulceration (Huffet al. 2006). In addition, dietary supplements, including fermented herbs, are also recommended because they appear to have anti-inflammatory properties, as demonstrated in vitro and in rats (Bose et al. 2012).

The purpose of the study was to evaluate the effects of two commercial dietary supplements on gastric mucosa in weanlings. Both supplements are thought to have a protective effect on gastric mucosa either by the buffering effect of $\mathrm{MgO}$ 
or due to the improvement of the fermentation profiles of fermented herbs. We used weaning as a model to induce gastric mucosa lesions. We hypothesized that the grade of gastric mucosa lesions is attenuated by feeding gastric protective supplements.

\section{Materials and Methods}

\section{Animals}

On one stud farm, 61 warmblood foals (26 females, 35 males) with a mean BW $( \pm$ SD) of $256 \pm 29 \mathrm{~kg}$ were included in the study. Foals aged between 6 and 8 months at weaning without any statistically differences between treatment groups. Prior to the study, the foals were maintained in groups of 10 mares and foals in barns $\left(27 \times 9 \mathrm{~m}^{2}\right)$ with free access to a paddock $\left(17 \times 9 \mathrm{~m}^{2}\right)$. In the barns, the animals were bedded on straw. Mares and suckling foals were fed daily with hay ad libitum and with a total mixed ration (TMR) of $\sim 9 \mathrm{~kg}$ (as fed) per mare and suckling foal. The TMR was formulated to meet or exceed the mares' energy and nutrient requirement. In particular, the TMR for each mare included $3 \mathrm{~kg}$ of corn silage, $3 \mathrm{~kg}$ of grass silage, $2 \mathrm{~kg}$ of oat, $0.5 \mathrm{~kg}$ of straw, $0.3 \mathrm{~kg}$ of soybean meal, $0.05 \mathrm{~kg}$ of a commercial mineral vitamin supplement and $0.04 \mathrm{~kg}$ of $\mathrm{CaCO}_{3}$. The TMR was provided once daily in the morning. Hay and water were provided ad libitum.

Weaning was performed on one day for all foals. For weaning, mares and foals were separated from each other and housed in different locations on the stud farm. After weaning, foals were randomly allocated to one of three treatment groups. The foals (up to 21) were housed together in the same barns $\left(27 \times 9 \mathrm{~m}^{2}\right)$ as before with free access to a paddock $\left(17 \times 9 \mathrm{~m}^{2}\right)$. In the barn, weaned foals were bedded on straw. During the treatment period, all of the groups were fed $8 \mathrm{~kg}$ (as fed) of the TMR to meet or to exceed the foals' energy and nutrient requirement. The TMR for each foal consisted of $2.2 \mathrm{~kg}$ of oat, $0.4 \mathrm{~kg}$ of soybean meal, $30 \mathrm{~g}$ of $\mathrm{CaCO}_{3}$, and $60 \mathrm{~g}$ of a commercial mineral vitamin supplement. In addition, hay was provided ad libitum. Foals had free access to water at all times. The project was approved by the Ethics Committee for the Animal Rights Protection of the District Government, in accordance with the German legislation for animal rights and welfare. The stud farm owner agreed with the study protocol.

\section{Supplementation}

Immediately after weaning, the foals were randomly and blindly allocated to one of the supplementation groups. Both supplements were of the same lot and quality control had been tested by the manufacturers. The fermented herbs and herbs fortified with $\mathrm{MgO}$ were stored at room temperature $\left(18^{\circ} \mathrm{C}\right)$ due to the manufacturer's instruction. Weanlings of group 1 ( $n=21$; 13 male, 8 female) were used as the control and were fed TMR and hay ad libitum as previously described.

Group 2 ( $n=21 ; 12$ male, 9 female) were fed the basal diet of TMR, hay ad libitum and herbs fortified with magnesium oxide (MgO) a according to the manufacturer's instructions. Each foal received $150 \mathrm{~g}$ of this supplement containing hayfield herbs, oat flakes and $\mathrm{MgO}(1000 \mathrm{mg} / \mathrm{kg}$ feed as analyzed). During the experiment, the foals were supplemented with the same lot without exceeding the expiration date.

Group 3 ( $n=19 ; 10$ male, 9 female) was fed the basal diet of TMR, hay ad libitum and a fermented preparation of herbs consisting of a liquid (containing a mixture of 80 effective microorganism, not analyzed) and short-chaffed preparation of herbs, sugar cane molasses, flax seed and psyllium. ${ }^{b}$ During the experiment, the foals were supplemented with the same lot without exceeding the expiration date.

In the morning, any leftover feed from the previous day was collected and re-weighed. To ensure complete feed intake, supplements were diluted in $0.5 \mathrm{~L}$ of warm water $\left(50^{\circ} \mathrm{C}\right)$ and soaked up to 20 minutes according to the manufacturer's instructions. Next, the soaked supplements were mixed into $0.2 \mathrm{~kg}$ of TMR. Foals of the control group were fed $0.2 \mathrm{~kg}$ of TMR mixed with water but without any supplement. The supplements were fed once daily at 09:00, and supplements were provided to the foals under visual monitoring. Foals were allowed to consume the supplements for a maximum of $30 \mathrm{~min}$. After complete feed intake, the foals received TMR and hay once daily as previously described. Foals were fed the respective supplements for 16 days.

\section{Gastroscopy}

Gastroscopy was performed 2 days before weaning and after 16 days of supplementation. Before gastroscopic examination, milk and feed were withheld for 6-12 hours. For gastroscopy, all weanlings were sedated with $0.02 \mathrm{mg} / \mathrm{kg}$ Detomidinhydrochloridc intravenously. A flexible 3-m endoscope ${ }^{d}$ was used.

The following regions of the stomach were examined separately: Saccus caecus, Curvatura major and minor of the Pars nonglandularis, Curvatura major of the Pars glandularis, the pylorus and proximal duodenum. Lesions were blinded graded by one experienced investigator (M. V.) using the scoring system validated by Andrews et al. (1999), which was adapted for each gastric region separately (Appendix).

\begin{tabular}{cl}
\hline Tabelle 1 & Lesion grading system by Equine gastric ulcer council Andrews et al. 1999 \\
\hline Grade & Description \\
\hline 0 & Epithelium intact and no appearance of hyperaemia (reddening) or hyperkeratosis \\
1 & Mucosa intact, but areas of reddening or hyperkeratosis (squamous) \\
2 & Small, single or multifocal lesions \\
4 & Small, single or multifocal lesions or extensive superficial lesions \\
\hline
\end{tabular}




\section{Scaling}

Bodyweight was measured using an electronic weight scale. ${ }^{\mathrm{e}}$ Immediately before the first and second gastroscopy. Feedstuffs were weighed using an automatic scale. ${ }^{\text {f Supplements }}$ were weighed using an electronic scale. ${ }^{9}$

\section{Statistical analysis}

BW data were expressed as the mean \pm SD or as a percentage of BW. The stomach scores were presented as the median, $25 / 75 \%$ percentile, minimum and maximum. Data analysis was performed using a statistical software program (STATISTI-

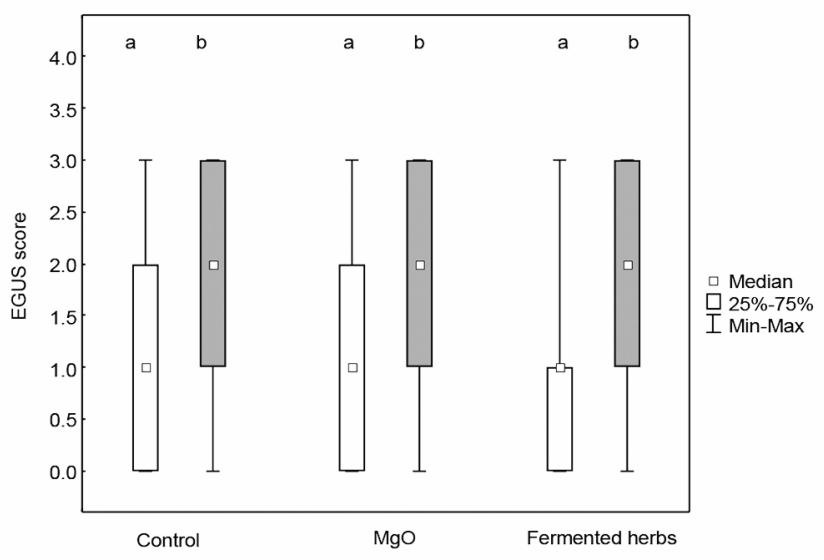

Fig. 1 EGUS score for Curvatura minor of the Pars nonglandularis before and after weaning for the different feeding groups (control $\mathrm{N}=21, \mathrm{MgO}=21$, fermented herbs $\mathrm{N}=19$ ). Data were expressed as the median, $25 / 75 \%$ percentile, minimum and maximum score. The white bars reflect the EGUS score before weaning, and the gray bars reflect the EGUS score after weaning for the different feeding groups. The medians with unlike lowercases are different with $p<0.05$.

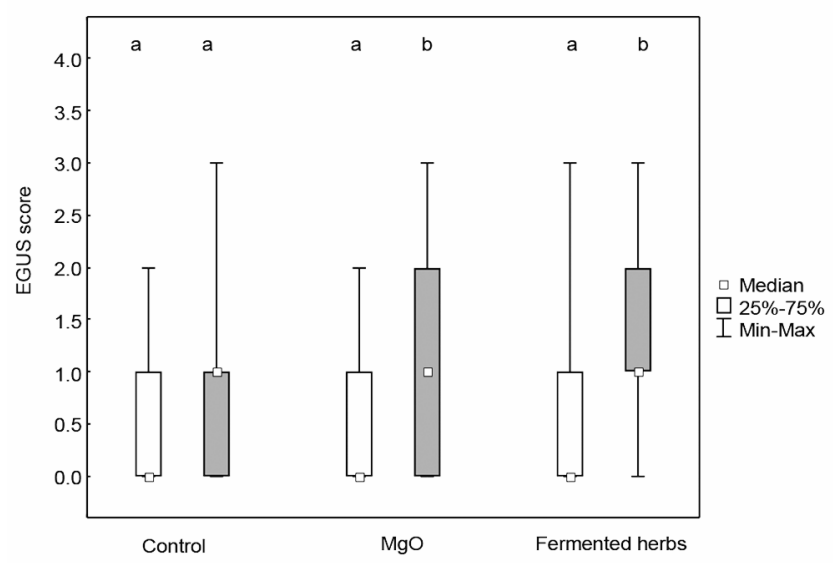

Fig. 2 EGUS score for Curvatura major of the Pars nonglandularis before and after weaning for the different feeding groups (control $\mathrm{N}=21, \mathrm{MgO}=21$, fermented herbs $\mathrm{N}=19$ ). Data were expressed as the median, $25 / 75 \%$ percentile, minimum and maximum score. The white bars reflect the EGUS score before weaning, and the gray bars reflect the EGUS score after weaning for the different feeding groups. The medians with unlike lower cases are different with $\mathrm{p}<0.05$.
KA, StatSoft). Data for BW were normally distributed using Shapiro-Wilk W test. The Wilcoxon signed rank test was used to compare the differences within a group before and after weaning. Kruskal-Wallis ANOVA was performed to compare the different treatment groups. Statistical significance was established at $\mathrm{p}<0.05$.

\section{Results}

Before weaning, the mean bodyweight of the foals was $262 \pm 25 \mathrm{~kg}$ for the control group, $252 \pm 28 \mathrm{~kg}$ for the $\mathrm{MgO}^{\text {a }}$ group, and $254 \pm 254 \pm 34 \mathrm{~kg}$ for feeding additionally fermented herbsb group $(p>0.05)$. During the experimental

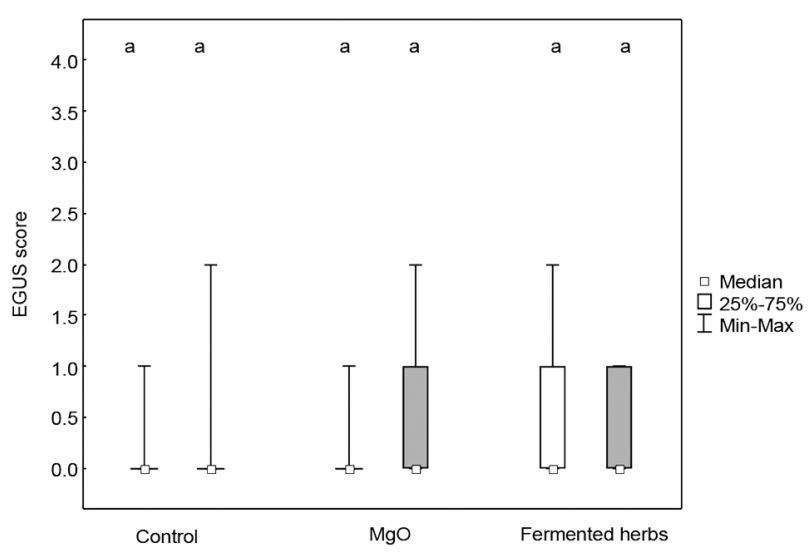

Fig. 3 EGUS score for Curvatura major of the Pars glandularis before and after weaning for the different feeding groups (control $\mathrm{N}=21, \mathrm{MgO}=21$, fermented herbs $\mathrm{N}=19$ ). Data are expressed as median, $25 / 75 \%$ percentile, minimum and maximum score. White bars reflect EGUS score before weaning, grey bars reflect EGUS score after weaning for the different feeding groups. Medians with unlike lower cases are different with $p<0.05$

period, foals' bodyweight increased significantly by approximately 2.4 to $3.5 \%$ of BW (TMR: $3.5 \pm 3.6 \%$, TMR and $\mathrm{MgO}^{\mathrm{a}}: \quad 2.9 \pm 4.6 \%$ and TMR+fermented herbs ${ }^{\mathrm{b}}$ : $2.4 \pm 4.3 \%$, treatment $p>0.05)$.

The feed intake was controlled every morning, and there were no feed refusals during the entire observation period. The mean daily dry matter intake of the basal ration was $7.2 \mathrm{~kg}$ $(2.77 \mathrm{~kg} / 100 \mathrm{~kg} \mathrm{BW})$ for each weanling in the control, $\mathrm{MgO}^{a}$ and fermented herbb group. During the entire observation period, there were no feed refusals of the supplements.

Before weaning, the prevalence of gastric mucosa lesions ( $\geq$ one lesion considering all locations in the stomach) was $82 \%$, and the lesions were mainly found in the Pars nonglandularis of Curvatura minor (median score 1, 25/75\% percentile: $0 / 2$, Figure 1) and Curvatura major (median score 0 , 25/75\% percentile: 0/1, Figure 2). None of the foals showed any clinical signs that are commonly related to the presence of gastric mucosa lesions, such as poor body condition, colic, slow eating or depression.

After weaning, the prevalence of gastric mucosal lesions was $96.7 \%$. Gastric mucosa lesions increased significantly in the 
Pars nonglandularis of the Curvatura minor, from a median score of 1 (25/75 percentile: 0/2) to a median score of 2 (25/75\% percentile: 1/3, Figure 1), and in the Antrum pyloricum, from a median score of $0(25 / 75 \%$ percentile: $0 / 0)$ to a median score of 1 (25/75 percentile: $0 / 2)$ in all groups (weaning $\mathrm{p}<0.05$, Figure 4). However, in the group that was provided feed supplementation with $\mathrm{MgO}^{\mathrm{a}}$ or fermented herbs $^{b}$, weaning also induced significantly higher gastric mucosa lesions in the Pars nonglandularis of the Curvatura major (Figure 2) and pylorus (Figure 5). No gastric mucosa lesions were found in the Saccus caecus or in the proximal duodenum before or after weaning (data not shown). Gastric mucosa lesions in the Pars glandularis of the Curvatura major increased in the $\mathrm{MgO}^{a}$ and fermented herb group ${ }^{b}$; however, without statistical significance (Figure 3).

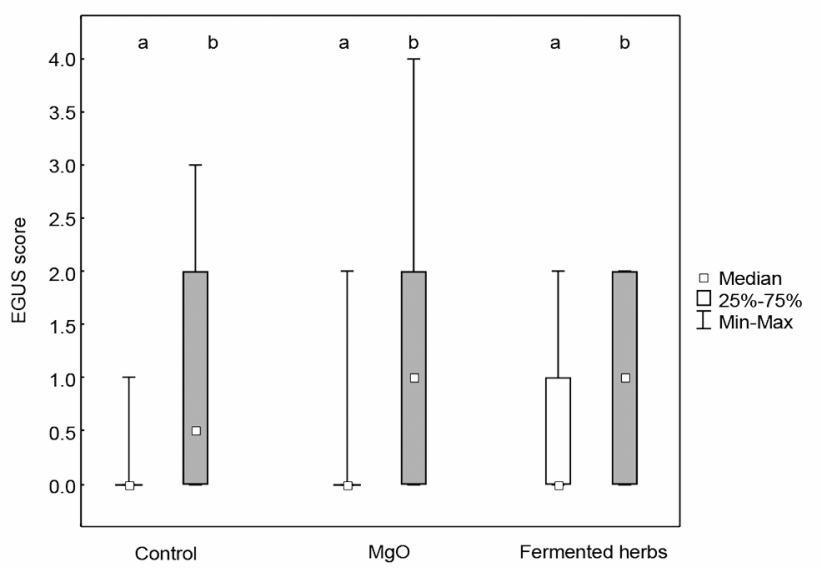

Fig. 4 EGUS score for Antrum pyloricum of the Pars glandularis before and after weaning for the different feeding groups (control $\mathrm{N}=21, \mathrm{MgO}=21$, fermented herbs $\mathrm{N}=19$ ). Data were expressed as the median, $25 / 75 \%$ percentile, minimum and maximum score. The white bars reflect the EGUS score before weaning, and the gray bars reflect the EGUS score after weaning for the different feeding groups. The medians with unlike lowercases are different with $p<0.05$.

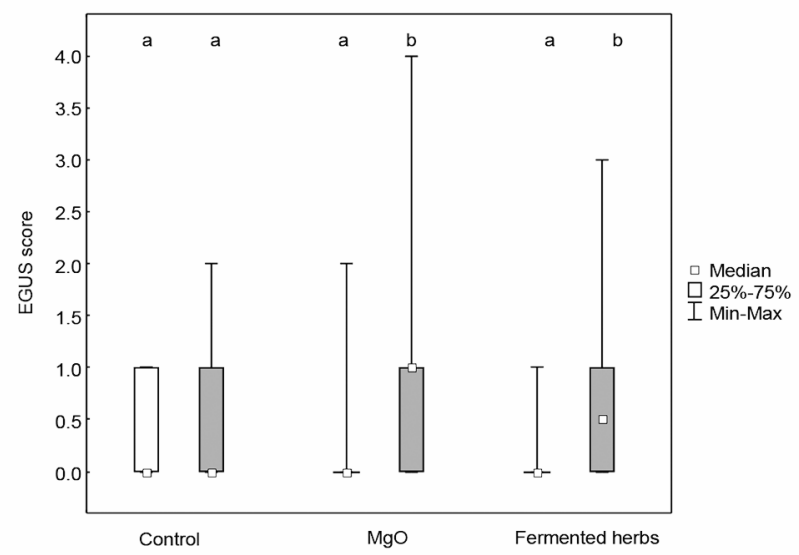

Fig. 5 EGUS score for pylorus before and after weaning for the different feeding groups (control $\mathrm{N}=21, \mathrm{MgO} \mathrm{N}=21$, fermented herbs $N=19$ ). Data were expressed as the median, $25 / 75 \%$ percentile, minimum and maximum score. The white bars reflect the EGUS score before weaning, and the gray bars reflect the EGUS score after weaning for the different feeding groups. The medians with unlike lowercases are different with $p<0.05$.

\section{Discussion}

There are several options to investigate the effects of drugs, gastric protective supplements or feeding management on EGUS. One is the usage of clinically ill horses showing typical symptoms of EGUS, such as colic, weight loss, decrease in performance and appetite (Ferrucci et al. 2003, Venner et al. 1999). Another option is to induce gastric lesions by repeating fasting and feeding periods (Murray and Grady 2002). Furthermore, stressful conditions, such as weaning or strenuous exercise, are suitable models to induce gastric lesions in foals or horses. Previous studies have shown that the abrupt weaning process is associated with increased gastric ulcers in foals (Dahlkamp et al. 2012, Pfaff et al. 2014).

Unexpectedly, the prevalence of gastric mucosa lesions ( $\geq$ one lesion considering all of locations in the stomach) in our population was already very high before weaning (Curvatura minor of the Pars nonglandularis median score 1 and Curvatura major median score 0), but without any clinical relevance. Changes in feeding and housing management two weeks before the start of the experiment most likely resulted in the high gastric lesion scores. Introduction into new housing and grouping were performed to ensure adequate intake of the respective supplements and to control the amount of any feed refusals. Medical treatments, such as omeprazole, have been shown to reduce the prevalence of gastric mucosal lesions in adult horses as well as in weanlings (Lester et al. 2005, Sykes et al. 2014, Birkmann et al. 2014). In particular, mucosal lesions located in the Pars nonglandularis demonstrated significantly better healing compared to lesions in the Pars glandularis (Dahlkamp et al. 2012). With respect to buffers the low gastric $\mathrm{pH}$, the use of antacid drugs, such as aluminum sucrose sulfate (sucralfate) or $\mathrm{MgO}$, was shown to reduce gastric ulcers in humans (Miyake et al. 1980).

Consistent with findings obtained in humans, similar results were found in horses. For example, a single oral application by a nasogastric tube of $30 \mathrm{~g}$ of aluminum hydroxide combined with $15 \mathrm{~g}$ of magnesium hydroxide resulted in a significantly higher gastric $\mathrm{pH}>4$ for at least 2 hours in five healthy horses (Clark et al. 1996). In addition, a single administration of an antacid drug combination containing $5.4 \mathrm{~g}$ or $8.1 \mathrm{~g}$ of aluminum hydroxide and $4.8 \mathrm{~g}$ or $7.2 \mathrm{~g}$ of magnesium hydroxide increased the gastric $\mathrm{pH}$ values in five healthy adult horses (Murray and Grodinsky 1992). The authors compared the effect of antacid drugs and $\mathrm{H}_{2}$-receptor antagonists on the gastric fluid $\mathrm{pH}$ over a period of 6 hours. However, only horses without gastric mucosa lesions were included in this study (Murray and Grodinsky 1992). In the present study, MgO fortified with herbs was supplemented to the foals. The weanlings did not show a reduction in gastric mucosa lesions within a 16-day supplementation period. The $\mathrm{MgO}$ intake corresponded to an amount of $150 \mathrm{mg}$ in each foal. The dosage in the present study was performed according to the manufacturer's instructions. In comparison to Murray and Grodins$k y$ (1992), relatively higher dosages of $\mathrm{MgO}(4.8 \mathrm{~g}$ and $7.2 \mathrm{~g}$ ) were used; thereby resulting in an increase in the gastric $\mathrm{pH}$ to 6 over a transient period of 15 and 30 minutes. Moreover, the buffering effect of these antacid drugs was short and the dosage of $\mathrm{MgO}$ in the present study was very low; thus, it remains unclear whether more frequent and higher $\mathrm{MgO}$ supplementation could improve gastric mucosa lesions. 
Supplementation of fermented herbs is thought to have antiinflammatory and anti-oxidative effects in vitro and in a rat model (Bose et al. 2012). In murine macrophage cell lines exposed to lipopolysaccharides as an inducer of systemic inflammation, different dosages of fermented and unfermented herb extracts were tested (Bose et al. 2012). The measurement of nitric oxide as a marker of inflammation decreased significantly in cells treated with fermented herbs compared to unfermented herbs and control. These results were further confirmed in a rat model (Huffet al. 2006). Rats were fed with either fermented or unfermented herbs, water and colostrum over a period of 6 days. After an intraperitoneal injection of lipopolysaccharides, serum concentrations of endotoxin and C-reactive protein were analyzed for up to 48 hours. Fermented herbs had a significant anti-inflammatory effect by reducing the serum concentrations of $\mathrm{C}$-reactive protein and endotoxin. In addition, gut permeability determined by measuring urine lactulose and mannitol decreased significantly in rats fed with fermented herbs (Bose et al. 2012).

The results of our study did not show any improvement in gastric mucosa lesions in weanlings fed with fermented herbs. However, the reasons for these results are not fully understood. One likely explanation might be the interaction between shortchain fatty acids produced during the fermentation process of the herbs and gastric mucosa. For example, Nadeau et al. (2003) identified a negative effect of high butyrate concentrations on the nonglandular gastric mucosal sodium transport system in vitro, thereby inducing inflammatory swelling of the cells. Herbs used for fermentation are available in various compositions. For example, Jung et al. (2010) used Curcuma, Houttuynia cordata, and Japanese apricot. Species of raspberry native to Korea, Japan and China as well as red ginseng were utilized by Chang et al. (2013). These dried herbs are inoculated or mixed together with specific bacteria, such as Leuconostoc mesenteroides or Bacillus licheniformis for fermentation (Bose et al. 2012). It cannot be excluded that during the fermentation process, in addition to the production of short chain fatty acids, other metabolites may also be produced. Short chain fatty acids or other metabolites may interact with cellular transport systems and result in gastric mucosal lesions or other harmful effects might be possible.

Weaning can be used as a model to induce gastric ulceration. Currently, $\mathrm{MgO}$ is widely used as a buffer in commercial gastric protective supplements in horses of all ages to prevent EGUS. However, we could not find any beneficial effects on gastric mucosa health in weanlings, most likely due to its low buffering capacity. Further protective supplements, including fermented herbs, have been proposed to exhibit anti-inflammatory effects, potentially by changing the fermentation profiles in the stomach. The assumed effects of fermented herbs were not be supported by our results. In order to reduce the incidence of EGUS during the weaning process, further studies should focus on the optimal weaning procedure rather than feeding gastric protective supplements.

\section{Manufacturer's addresses}
a Allequin Gastro 2, Almapharm GmbH und Co KG Kemp- ten, Germany
b EM Chiemgau, Christoph Fischer $\mathrm{GmbH}$, Germany

c Domosedan ${ }^{\circledR}$, Elanco Animal Health, Bad Homburg, Germany

d Karl Storz, Tutlingen, Germany

e Müller, Jagstzell, Germany

f Mettler PM 16-k, Mettler Toledo, Gießen, Germany

g Mettler PJ 3600, Delta Range, Gießen, Germany

\section{References}

Al Jassim R. A., Andrews F. M. (2009) The bacterial community of the horse gastrointestinal tract and its relation to fermentative acidosis, laminitis, colic and stomach ulcers. Vet. Clin. North Am. Equine Pract. 25, 199-215

Andrews F.; Bernard W.; Byars D., Cohen N., Divers T., MacAllister C., McGladdery A., Merritt A., Murray M., Orsini J., Snyder J., Vatistas N. (1999) Recommendations for the diagnosis and treatment of equine gastric ulcer syndrome (EGUS). Equine Vet. Educ. $11,262-272$

Birkmann K., Junge H. K., Maischberger E. (2014) Efficacy of omeprazole powder paste or enteric-coated formulation in healing of gastric ulcers in horses. J. Vet. Intern. Med. 28, 925-933

Bose S., Song M. Y., Nam J. K., Lee M. J., Kim H. (2012) In vitro and in vivo protective effects of fermented preparations of dietary herbs against lipopolysaccharide insult. Food Chemistry 134, 758-65

Chang M. K., Seong J. Y., II J. C., Sae K. K. (2013) Red-Koji fermented red ginseng ameliorates high fat diet-induced metabolic disorders in mice. Nutrients 5, 4316-4332

Clark C. K., Merritt A. M., Burrow J. A., Steible C. K. (1996) Effect of aluminum hydroxide/magnesium hydroxide antacid and bismuth subsalicylate on gastric $\mathrm{pH}$ in horses. Am. J. Vet. Med. Assoc. 208, 1687-1691

Coenen M., Kienzle E., Vervuert I., Zeyner A. (2011) Recent German developments in the formulation of energy and nutrient requirements in horses and the resulting feeding recommendations. Journal of Equine Vet. Sci. 31, 219-229

Contreras M., Morales A., Garcia-Amado M. A (2007): Detection of Helicobacter like DNA in the gastric mucosa of thoroughbred horses. Letters in applied Microbiology, 553-557

Dahlkamp M., Feige K., Venner M. (2012) Gastric lesions in foals before and after weanling: Influence of Omeprazole. Pferdeheilkunde 28, 561-569

Ferruci F., Zucca E., Croci C., Di Fabio V., Ferro E. (2003) Treatment of gastric ulceration in 10 standardbred racehorses with a pectinlecithin complex. Vet. Rec. 31, 679-681

Hammond C. J., Mason D. K., Watkins K. L. (1990) Gastric ulceration in mature thoroughbred horses. Equine Vet. J. 18, 284-287

Huff N. K., Auer A. D.; Garza J. K., Keowen M. L., Kearney M. T., McMullin R. B., Andrews F. M.(2006) Effects of sea buckthorn berries and pulp in a liquid emulsion on gastric ulcer scores and gastric juice $\mathrm{pH}$ in horses. J. Vet. Intern. Med. 26, 1186-1191

Jung B. G., Ko J. H., Lee B. J. (2010) Dietary supplementation with a probiotic fermented four-herb combination enhances immune activity in broiler chicks and increases survivability against Salmonella Gallinarum in experimentally enfected broiler chicks. J. Vet. Med. Sci. 72, 1565-73

Lester G. D., Smith R. L., Robertson I. D. (2005) Effects of treatment with omeprazole or ranitidine on gastric squamous ulceration in racing thoroughbreds. J. Am. Vet. Med. Assoc. 227, 1636-9

Miyake T., Ariyoshi J., Oishi M., Sakai M., Ueda S. (1980) Endoscopic evaluation of the effect of sucralfate therapy and other clinical parameters on the recurrence rate of gastric ulcers. Digest. Diseas. Scienc. 25, 1-7

Murray M. J., Grodinsky C. (1992) The effect of famotidine, ranitidine and magnesium hydroxide/aluminium hydroxide on gastric fluid $\mathrm{pH}$ in adult horses. Equine Vet. J. Supplement 1 1, 52-55

Murray M. J. (1994) An equine model inducing alimentary squamous epithelial ulceration. Digest. Diseas. Scienc. 12, 2530 2535 
Murray M. J., Eichorn E. S. (1996) Effects of intermittent feed deprivation, intermittent feed deprivation with ranitidine, and stall confinement with free access to hay on gastric ulceration in horses. Am. J. Vet. Res. 57, 1599-1603

Murray M. J. (1999) Pathophysiology of peptic disorders in foals and horses: a review. Equine Vet. J. Supplements 29, 14-8

Murray M. J., Grady T. C. (2002) The effect of a pectin-lecithin complex on prevention of gastric mucosal lesions induced by feed deprivation in ponies. Equine Vet. J. 34, 195-198

Nadeau J. A., Andrews F. M., Patton C. S., Argenzio R. A., Mathew A. G., Saxton A. M. (2003) Effects of hydrogenic, acetic, butyric and proionic acids on pathogenesis of ulcers in the nonglandular portion of the stomach of horses. Am. J. Vet. Res. 64, 404-412

Pfaff M. (2014) Effects of different roughage-based diets on the gastric mucosa in weanlings. Diss. Med. vet. Hannover

Sanz M. G., Vilioen A., Saulez M. N., Olorunju S., Andrews F. M. (2014) Efficacy of a pectin-lecithin complex for treatment and prevention of gastric ulcers in horses. Vet. Rec. 18, 1-4

Sykes B. W., Sykes K. M., Hallowell G. D. (2014) A comparison of three doses of omeprazole in the treatment of equine gastric ulcer syndrome: a blinded, randomized, dose-response clinical trial. Equine Vet. J. 46, 416-421

Vatistas N. J., Synder J. R, Carlson G. P., Johnson B., Arthu R. M., Thurmond M., Zhou H., Lloyd K. L. K. (1994) Epidemiology study of gastric ulceration in the Thoroughbred race horse; 202 cases. Proceedings Annual Convention American Association of Equine Practitioners, Vancouver, British Columbia, Canada; 125-126

Venner M., Lauffs S., Deegen E. (1999) Treatment of gastric lesions in horses with pectin-lecithin complex. Equine Vet. J. Supplement; 29, $91-96$

Vervuert I., Voigt K., Hollands T., Cuddeford D., Coenen M. (2009) Effect of feeding increasing quantities of starch on glycaemic and insulinaemic responses in healthy horses. Vet. J. 182, 67-72

\section{Erweiterte Zusammenfassung}

\section{Wirkung von Ergänzungsfuttermitteln auf die Magenschleimhaut bei Absetzfohlen}

Unter dem Begriff Equine Gastric Ulcer Syndrome entsprechend der Lokalisation präziser Equine Squamous Gastric Disease (ESGD) und Equine Glandular Gastric Disease (EGGD), werden Magenulzera sowie damit einhergehende klinische Symptome zusammengefasst. Mit einem Vorkommen von mehr als $80 \%$ bei Vollblutpferden und 30 bis $50 \%$ bei Fohlen, speziell Absetzfohlen, stellt dies eine weit verbreitete und bekannte Erkrankung dar. Die Pathogenese der Magenulzera scheint im Allgemeinen sowohl in der kutanen als auch in der drüsenhaltigen Schleimhaut als sehr vielfältig. Ursächlich bekannte Risikofaktoren in der Entstehung von Magenschleimhautläsionen sind nichtsteroidale Antiphlogisti$\mathrm{ka}$, hohe Krafffuttermengen, Hungerperioden von über 24 Stunden, hohe sportliche Leistungen und Transportstress. Daneben führen eine kontinuierliche Magensäureproduktion durch die Parietalzellen, sowie auch das Einwirken von Gallensäuren oder kurzkettigen Fettsäuren auf die Magenschleimhaut zu schwerwiegenden Reizungen und Schädigungen der Magenschleimhaut. Eine synergistische Wirkungsweise zur Salzsäure haben die im Rahmen der Fermentation entstehenden kurzkettigen Fettsäuren wie Acetat, Proprionat und Butyrat. Diese führen zu einer Zellschwellung der Magenschleimhaut mit einhergehender Entzündung und Blockade des transzellulären Natriumtransportsystems. Identische Wirkungen auf die Magenschleimhaut in Form einer Permeabilitätserhöhung sowie sekundär deren Schädigung wird durch das Laktat verursacht. Dieses weitere Stoffwechselprodukt entsteht infolge der Kohlenhydratfermentation durch die Mikroflora im Magen.

In der Behandlung der Magenulzera sollte der erste Schritt die Optimierung der Fütterungs- und Haltungsbedingungen sein. Im nächsten Schritt ist die Anwendung von Arzneimitteln gerade bei wahrnehmbaren klinischen Symptomen anzuraten. Daneben sind zur Prävention und Unterstützung in der Heilungsphase zahlreiche diätetische Ergänzungsfuttermittel im Handel frei verfügbar. Mit dieser Studie soll daher geklärt werden, ob mit der Fütterung diätetischer Ergänzungsfuttermittel bei Absetzfohlen eine Verbesserung der Magenschleimhautbefunde erreicht werden kann.

In die Studie konnten 61 Warmblutfohlen (26 Stuten, 35 Hengste) mit einem mittleren Alter von 6 bis 8 Monaten einbezogen werden. Stuten und Fohlen wurden vor Studienbeginn in großen Gruppen auf einer Weide gehalten. Zwei Wochen vor dem Versuch wurden diese Tiere in einen Laufstall mit angrenzendem Paddock gebracht. Die Fütterung deckte den Energie- und Nährstoffbedarf der Fohlen und beinhaltete eine einmal täglich gefütterte Mischfutterration (TMR) von $\sim 9 \mathrm{~kg}$ (TS) bestehend aus $3 \mathrm{~kg}$ Maissilage, $3 \mathrm{~kg}$ Grassilage, $2 \mathrm{~kg}$ Hafer, $0,5 \mathrm{~kg}$ Stroh, $0.3 \mathrm{~kg}$ Sojaschrot, $0,05 \mathrm{~kg}$ Mineralfutter und $0,04 \mathrm{~kg}$ Futterkalk sowie Heu ad libitum. Nach dem Absetzen wurden die Fohlen randomisiert und verblindet eine der drei Gruppen zugeordnet und erhielten jeweils ein Ergänzungsfuttermittel über 16 Tage. Gruppe 1 diente als Kontrollgruppe und erhielt ausschließlich die TMR und Heu. Die Gruppe 2 erhielt entsprechend den Herstellerangaben einmal täglich Magnesiumoxid zusätzlich zu der TMR und Heu. Fermentierte Kräuter, bestehend aus einer flüssigen und einer gehäckselten Komponente bildeten neben der TMR und Heu die Fütterung der Gruppe 3. Täglich erfolgte die Rückwaage übrig gebliebener Futterreste vom Vortag. Alle Fohlen wurden gastroskopisch zwei Tage vor dem Absetzen und 16 Tage nach der Fütterung untersucht. Hierbei wurden insgesamt folgende sechs Magenregionen getrennt nach dem Scoring System von Andrews et al. (1999) beurteilt: Saccus caecus, Curvatura major und minor der Pars nonglandularis, Curvatura major der Pars glandularis, Pylorus und proximales Duodenum.

Insgesamt lag die tägliche Trockenmasseaufnahme bei $7,2 \mathrm{~kg}$ $(2,77 \mathrm{~kg} / 100 \mathrm{kgKG})$ pro Absetzfohlen. In der Curvatura major und minor der Pars nonglandularis lag die Prävalenz der Magenschleimhautläsionen bereits vor dem Absetzen bei $82 \%$. Zu keinem Zeitpunkte zeigte ein Fohlen klinische Anzeichen wie Kolik oder verlangsamtes Fressverhalten welche im Zusammenhang mit Magenulzera stehen könnten. Die Häufigkeit der Magenbefunde stieg allerdings nach dem Absetzen auf $96,7 \%$ an. In allen Gruppen kam es in den Bereichen Curvatura minor der Pars nonglandularis sowie Antrum pyloricum zu einem statistisch signifikanten Anstieg der Magenschleimhautläsionen. In beiden Gruppen, die Ergänzungen erhalten hatten, ließen sich an der Curvatura major der Pars nonglandularis und am Pylorus statistisch signifikant mehr Magenschleimhautläsionen feststellen.

Die Induzierung von Magenulzera mithilfe des Absetzmodells der Fohlen von den Stuten stellt ein geeignetes Verfahren in der Untersuchung magenprotektiver Substanzen dar. Evaluiert 
wurden diese Substanzen auch in Futterentzugsmodellen oder in Studien mit klinisch erkrankten Pferden. In der eigenen untersuchten Population lag die Prävalenz der Magenschleimhautläsionen bereits zu Beginn unerwartet hoch, ohne dass bei einem Fohlen klinische Symptome sichtbar waren. Als mögliche Ursache für diese hohe Prävalenz kommt die zwei Wochen vor Studienbeginn stattgefundene Umstellung von der Weidehaltung in einen Laufstall mit Paddock in Betracht.

Zur Behandlung von Magenulzera wird Omeprazol als das Mittel der Wahl sowohl bei adulten Pferden als auch bei Absetzfohlen angesehen. Weitere Substanzen wie Säureblokker, Sukralfat ${ }^{\circledR}$ oder Magnesiumoxid verzeichnen in der Humanmedizin in der Behandlung und Prävention von Magen-ulzera sehr gute Erfolge. Diese Produkte ließen sich mit Erfolg auch in der Tiermedizin einsetzen. Beispielsweise konnten Clark et al. (1996) zeigen, dass eine einmalige Gabe von $30 \mathrm{~g}$ Aluminiumhydroxid in Kombination mit Magnesiumhydroxid zu einer signifikanten Steigerung des $\mathrm{pH}$-Wertes im Magen von > 4 über einen Zeitraum von 2 Stunden bewirkt. Daneben steigt der $\mathrm{pH}$-Wertes des Magens von Pferden infolge der einmaligen oralen Eingabe von Aluminiumhydroxid über 6 über einen Zeitraum von 15 bis 20 min an (Murray und Grodinsky 1992). Hingegen konnte in der hiesigen Studie ein positiver Effekt zur Verbesserung der Magenschleimhautbefunde nach der Magnesiumoxid-Gabe oder auch durch fermentierte Kräuter bei den untersuchten Absetzern nicht beobachtet werden. Die angewendete Dosis entsprach den Herstellerangaben und ergibt $150 \mathrm{mg}$ pro Absetzfohlen. Vergleicht man die eigenen Ergebnisse mit denen von Murray und Grodinsky (1992) so verwendeten diese eine deutlich höhere Dosierung, allerdings untersuchten Murray und Grodinsky (1992) nur die
$\mathrm{pH}-$ Werte im Magen. Inwieweit Magnesiumoxid einen Effekt auf die Entstehung oder Abheilung von Magengeschwüren bewirkt, wurde von den Autoren nicht untersucht.

Durch die Fütterung von fermentierten Kräutern wurde neben einer Erhöhung des pH-Wertes des Magens und der damit einhergehenden Pufferungsfunktion bei Versuchstieren (Ratten) ein antiinflammatorischer und antioxidativer Effekt gezeigt. Als Parameter dienten die Messungen der Serumkonzentration des C-reaktiven Proteins (CRP) und des Endotoxingehaltes. Zusätzlich konnte bei den Ratten eine reduzierte Permeabilität des Magendarmtraktes mittels einer Laktulose und Mannitol Messsung im Urin festgestellt werden. Dennoch bleiben die Auswirkungen der fermentierten Kräuter auf die Magenschleimhaut kontrovers diskutiert. Ein positiver Effekt ließ sich bisher nicht nachweisen. Nicht auszuschließen ist, dass fermentierte Kräuter aufgrund der Bildung von kurzkettigen Fettsäuren durch die eingesetzten Bakterien auch Nachteile aufweisen können, so konnte z.B. in vitro gezeigt werden, dass kurzkettige Fettsäuren zu Zellödemen an der equinen Magenschleimhaut führen können (Nadeau et al. 2001). In der hier vorgestellten Studie konnte keine Verbesserung der Magenschleimhautläsionen durch den Einsatz von Ergänzungen wie das Magnesiumoxid oder die fermentierten Kräuter bei Absetzfohlen erreicht werden. Vermutlich resultiert dieses Ergebnis auf der nicht ausreichenden und nur kurzfristigen Anhebung des pH-Wertes des Magens. Es wird daher empfohlen in erster Linie den Absetzprozess zu optimieren bevor magenprotektive Substanzen zum Einsatz kommen.

Schlüsselwörter: EGUS / Magnesiumoxid / Fohlen / fermentierte Kräuter / Fütterung / Ergänzungsfuttermittel 